\title{
Rostos, afetos e intencionalidade: análise semiolinguística de marcas da pandemia
}

Faces, Affections and Intentionality: Semiolinguistic Analysis of Pandemic Brands

\section{Beatriz dos Santos Feres*}

beatrizferes@id.uff.br

https://orcid.org./0000-0001-5854-2898

\author{
Patrícia Ferreira Neves Ribeiro** \\ patricianeves@id.uff.br \\ https://orcid.org/0000-0001-9532-0098
}

\author{
Rosane Santos Mauro Monnerat ${ }^{* * *}$ (D) \\ rosanemonnerat@id.uff.br \\ https://orcid.org/0000-0003-2523-9088
}

\section{Resumo}

Neste artigo, propõe-se a análise de textos verbo-visuais - uma matéria de capa de jornal e uma publicidade veiculada em revistas - que apresentam, em comum, rostos femininos marcados, em alguma medida, por indícios da pandemia de covid-19. Essa análise tem como objetivo destacar recursos discursivos que implicitam ideias, emoções e intencionalidades de acordo, sobretudo, com o imaginário sociodiscursivo partilhado pelos interagentes da troca propiciada por esses textos, no intuito de contribuir com um embasamento teórico-analítico para a elaboração de atividades de interpretação voltadas para a "Educação Midiática" proposta pela Base Nacional Comum Curricular. Tendo como fundamento a Teoria Semiolinguística de Análise do Discurso em interface com outros estudos, serão explorados, inicialmente, os conceitos de imagem como signo, imagem-sintoma e intericonicidade. A seguir, tomando mais especificamente os textos em tela, será observada a construção do ethos e da visada patêmica na discursivização.

\footnotetext{
Universidade Federal Fluminense - UFF, Rio de Janeiro, Brasil; Instituto de Letras, Programa de PósGraduação em Estudos da Linguagem, Campus Gragoatá, Niterói, RJ, Brasil.

** Universidade Federal Fluminense - UFF, Rio de Janeiro, Brasil; Instituto de Letras, Programa de PósGraduação em Estudos da Linguagem, Campus Gragoatá, Niterói, RJ, Brasil.

*** Universidade Federal Fluminense - UFF, Rio de Janeiro, Brasil; Instituto de Letras, Programa de PósGraduação em Estudos da Linguagem, Campus Gragoatá, Niterói, RJ, Brasil.
} 
Palavras-chave: Verbo-visualidade; Ethos; Patemização; Mídia; Recursos discursivos.

\begin{abstract}
In this article, we propose the analysis of verb-visual texts - a newspaper cover story and an advertisement disclosed in magazines - which have in common marked female faces, to some extent, by evidence of the covid-19 pandemic. This analysis aims to highlight discursive resources that imply ideas, emotions and intentionalities in accordance, above all, with the sociodiscursive imaginary shared by the interactants of the exchange provided by those texts, in order to contribute with a theoretical-analytical basis for the elaboration of activities of interpretation focused on "Media Education" proposed by the National Common Basis. Based on the Semiolinguistic Theory of Discourse Analysis in liaison with other studies, the concepts of image as a sign, image -symptom and intericonicity will be initially explored. After that, taking the texts under analysis more specifically, the construction of the ethos and the controversial target in discursivization will be observed.
\end{abstract}

Keywords: Verb-visuality; Ethos; Patemization; Media; Discursive Resources.

\title{
Para ler imagens, palavras e a mídia
}

Imersos em um oceano virtual, navegando em redes digitais que aceleram a comunicação, a profusão de gêneros discursivos hipermidiáticos exige dos leitores (aqui em sentido amplo: interpretadores), além da celeridade própria do ciberuniverso, aptidão para compreender textos sintéticos, bastante complexos e, cada vez mais, multimodais. Esse novo ambiente social virtual acostuma-nos a leituras rápidas e, se não houver cuidado, superficiais, que podem contaminar nossa maneira de apreender a realidade e de enunciar. Nas redes sociais, o "textão" é, quase sempre, envolto por uma avaliação negativa - e preguiçosa -, que, de certa maneira, deixa evidenciar a preferência por um modo de comunicação mais "enxuto".

Assim, apostando nessa "economia textual", portais de notícias apresentam fatos em listas e fotos; em um primeiro clique, apenas título e subtítulo referentes à cena mostrada como prova, mas, conseguindo captar o leitor, em um segundo clique, ele terá o lead e outras informações. Também no jornalismo impresso, capas-cartazes, como as dos jornais populares, muitas vezes monotemáticas, apresentam uma formatação centralizada em imagens impactantes, títulos coloridos e enormes, com duplo sentido, humor e crítica (GUIMARÃES, 2020). É no curto espaço dessa capa que a notícia principal do dia é fornecida aos leitores, por meio da verbo-visualidade, em um conjunto complexo de formas e sentidos, em um texto rápido, ainda que exigente de muitos saberes partilhados e muito trabalho inferencial. A publicidade já sabia dessa necessária celeridade de captação do consumidor, investindo em peças sempre mais impactantes, que mexem com o afeto e com sua necessidade de pertença social. Nesta atualidade globalizada, em rede, de fácil participação e anonimato, surgem, então, novos gêneros, como o meme, e outros, antigos, ratificam um modelo comunicativo baseado, sempre mais, na compactação e no impacto.

\section{LINHA DÁGUA}


É esse modelo compacto e impactante de muitos gêneros digitais aos quais estão expostos os leitores nas variadas mídias - sobretudo nas digitais, mas também nas de suporte impresso - desse mundo globalizado que este artigo pretende problematizar. Mais do que atentar para os objetivos comunicativos e persuasivos que direcionam esse modelo, pretendese aqui, na perspectiva do leitor, observar "pistas" interpretativas que ajudam a tornar a leitura menos superficial e fragmentada. Para isso, foram selecionados dois textos oriundos de mídias de massa - um jornal e uma revista de grande circulação, tanto no ambiente virtual quanto no "real" - a fim de analisar alguns recursos discursivos de que esses textos se valem não só para informar o leitor, mas, especialmente, para captá-lo, seduzi-lo e convencê-lo. Com essa problematização, acredita-se contribuir para o embasamento teórico-analítico de professoresmediadores de leitura, preocupados com o desenvolvimento da competência leitora dos "interpretadores" de uma sociedade carente de crítica e de profundidade.

Soma-se a essa problematização a mais recente diretriz para o ensino no Brasil, expressa pela Base Nacional Comum Curricular (BNCC), que "procura contemplar a cultura digital, diferentes linguagens e diferentes letramentos, desde aqueles basicamente lineares, com baixo nível de hipertextualidade, até aqueles que envolvem a hipermídia” (BRASIL, 2017, p. 70). Ainda que haja muita discussão em torno da BNCC, seja em função de possíveis objetivos de um documento que preza a centralização curricular em um país continental e pluricultural como o Brasil, que pouco valoriza a docência, seja em função dos possíveis interesses em um modelo "privatista" de Educação (SELLES, 2018), o fato é que os professores precisam incorporar saberes e métodos para trabalhar, dentre outros aspectos, a "reconstrução e reflexão sobre as condições de produção e recepção dos textos pertencentes a diferentes gêneros e que circulam nas diferentes mídias e esferas/campos de atividade humana" e a "compreensão dos efeitos de sentido provocados pelos usos de recursos linguísticos e multissemióticos em textos pertencentes a gêneros diversos" (BRASIL, 2017, p. 72 e 73).

Ainda a respeito desse documento, é preciso salientar que

Leitura no contexto da BNCC é tomada em um sentido mais amplo, dizendo respeito não somente ao texto escrito, mas também a imagens estáticas (foto, pintura, desenho, esquema, gráfico, diagrama) ou em movimento (filmes, vídeos etc.) e ao som (música), que acompanha e cossignifica em muitos gêneros digitais. (BRASIL, 2017, p. 72).

Afinado a essa concepção de leitura, então, este trabalho desenvolverá três tópicos vinculados à interpretação de textos multissemióticos como aqueles que serão analisados: a imagem como signo; o ethos como estratégia de captação; e o pathos como efeito. A conceituação utilizada estará pautada prioritariamente na Teoria Semiolinguística de Análise do Discurso, formulada por Patrick Charaudeau (2013, 2010, 2008, 2006), em interface com outras teorias. O corpus será composto pela matéria de capa do jornal O Globo de 14 de maio de $2020^{1}$, na qual a fotografia do rosto de uma médica aparece machucado pelo uso dos

1 Disponível em https://acervo.oglobo.globo.com/consulta-ao-acervo/?navegacaoPorData=202020200514. Acesso em 29 out 2020.

\section{LINHA DÁGUA}


Equipamentos de Proteção Individual (EPIs) no embate na "linha de frente" contra a covid-19, e uma publicidade da joalheria HStern, veiculada em revistas como a Veja, na qual a estilista Constanza Pascolato, elegantemente vestida e adornada com vários anéis, cobre parcialmente o rosto, deixando à vista somente os olhos ${ }^{2}$.

Justifica-se a escolha dessas peças por se tratar de dois textos verbo-visuais de larga circulação pela mídia de massa (ainda que endereçados a públicos bastante específicos e não à população em geral), de domínios discursivos - jornalístico e publicitário - que oscilam entre o espaço virtual e o "real". Acredita-se que essa escolha possa sustentar interpretações comprometidas com o letramento midiático e com a análise crítica, tão necessária para a formação de cidadãos ativos em sua inserção social, seja ela em qualquer nível social ou esfera de atuação.

\section{A imagem como signo}

Como se propõe aqui a análise de dois textos multimodais compostos verbovisualmente, nesta seção, a atenção estará fixada na conceituação mesma de imagem como signo e de alguns aspectos relativos à discursivização próprios desse meio semiótico.

Em primeiro lugar, é preciso distinguir imagens mentais de imagens visuais (materiais): aquelas, próprias de um domínio imaterial, concretizam-se em visões, fantasias, imaginações, enfim, em representações mentais; estas, de um domínio material, concretizam-se em desenhos, pinturas, fotografias, imagens televisivas, infográficas, enfim, em representações exteriores à mente, apreendidas por meio da visão humana (SANTAELLA; NÖTH, 2005). Esses domínios estão inextricavelmente ligados. As imagens visuais, ou materiais, produzidas por meio de artefatos, se originam em imagens mentais que, muitas vezes, espelham a experiência visual direta no mundo "real" e, outras vezes, em memórias de outras imagens, antes, vistas, e agora, guardadas na mente. Já as imagens mentais, além de permitirem o armazenamento, na memória, de imagens apreendidas pela visão, também podem se originar em imaginações, em modificações de imagens já conhecidas, operadas na mente pela criatividade. Salienta-se, aqui, que as imagens mentais, como primeiro enquadramento do mundo, "resultado da percepção direta que um sujeito tem do mundo físico" (CHARAUDEAU, 2013, p. 383), constituem um relevante repertório mnemônico, impregnado de crenças e valores referendados socialmente, que podem ser acionados nas interpretações que fazemos das imagens materiais com as quais nos defrontamos, constituindo importantes modelos de processamento cognitivo.

Em segundo lugar, é preciso frisar que as imagens são signos, isto é, estão substituindo e indicando um dado do mundo ("real" ou imaginário); em outras palavras, não são

2 Disponível em https://www.facebook.com/hsternbrasil. Acesso em 29 out 2020. Na página do Facebook da HStern, é essa imagem que aparece como capa, embora a campanha publicitária seja composta por várias fotografias de Constanza Pascolato em situações diversas. A publicidade também está disponível no site da

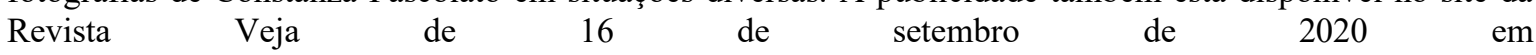
https://veja.abril.com.br/acervo/\#/edition/186185?page=10\&section=1. Acesso em 30 out 2020.

\section{LINHA DÁGUA}


efetivamente os elementos do mundo, mas substitutos que se referem a esses elementos e podem, ao mesmo tempo, simbolizar ideias convencionais partilhadas por um grupo social. Além disso, quando o sujeito capta e representa o mundo físico por intermédio de um artefato (em uma fotografia, por exemplo, por meio de uma câmera), ele produz uma imagem material em uma perspectiva própria, isto é, como reenquadramento do mundo físico (CHARADUEAU, 2013, p. 384). A materialidade dessa imagem produz, portanto, um efeito imediato de semiotização, já que passou por uma construção de sentido, permeada pelos recursos da aparelhagem utilizada para a apreensão da realidade física a partir do olhar daquele que a produz.

Além disso, segundo Barthes (1990), como signo, a imagem opera um sentido propriamente denotativo, literal (ainda que jamais em "estado puro", já que orientada pela perspectiva do produtor), indicial, mas também conotativo, simbólico, codificado socialmente. Mesmo em uma fotografia, que traz em si a credibilidade alcançada pela semelhança com a realidade que representa, seu "conteúdo" é passível de interpretação em função dos vínculos que mantém com sua "fonte física", com os saberes acumulados a respeito dela e com a percepção de possíveis recursos que acrescentam sentidos e efeitos à materialidade da imagem fotografada. Quando se trata de fotografia "profissional", seja da imprensa, seja da publicidade, somam-se à sua materialidade aspectos próprios de sua manipulação, como ângulo; luz; distância; foco; escolha, preparação e pose do objeto; edição etc., tornando-a acentuadamente "preparada" para a conotação.

Considerando, então, o papel da imagem material como signo, é possível pensar no papel do "leitor":

Se nos colocamos do lado do processo de recepção da imagem, temos um sujeito que olha a imagem como mundo representado, através de um determinado modo de representação que desempenha um duplo papel de substituição (uma imagem é dada por um objeto físico do mundo) e de mostração (este objeto é exibido). Outro sujeito se encontra, então, em um lugar de recepção da imagem no qual ele é convidado a desenvolver uma dupla atividade: o sentimento dos efeitos da imagem de acordo com sua própria sensibilidade e a interpretação da imagem segundo sua própria inteligibilidade. (CHARAUDEAU, 2013, p. 384)

Dessa forma, para além do "sentimento dos efeitos da imagem", quase sempre tomado como uma impressão imediata no momento da apreensão visual daquele texto, o sujeito que olha a imagem passa à sua interpretação, isto é, faz inferências a respeito daquele signo-texto de acordo com sua memória discursiva, com seu repertório imagético armazenado na mente e com o entorno dessa imagem. Pode-se afirmar, então, que muitas inferências realizadas pelo leitor se baseiam em informações extratextuais, guardadas na memória, seja quanto a aspectos discursivos relacionados à forma ali representada, seja quanto a aspectos avaliativos. Segundo Charaudeau (2018), essas são as inferências centrífugas, que se baseiam em dados interdiscursivos e situacionais. Outras inferências, como veremos, dizem respeito à relação estabelecida entre a imagem e uma parcela verbal com a qual ela se relaciona no conjunto do qual participa. No caso das imagens fotográficas, um dos alvos de nosso interesse, Barthes

\section{LINHA DÁGUA}


(1990) já adiantava que a palavra teria a função de fixar, ancorar a cadeia flutuante de significados oferecida pela imagem com a qual está vinculada. Em termos de interpretação, essa ancoragem estaria, em primeiro plano, no terreno das inferências centrípetas (CHARAUDEAU, 2018) realizadas, nesse caso, entre os elementos verbal e visual, observados na organização "sintática" do texto, que obriga o leitor a uma leitura em um "círculo hermenêutico", que parte do todo para os detalhes, e vai da imagem à palavra e vice-versa.

Como Charaudeau (2013, p. 385), pensamos que "a imagem é toda opacidade que obriga a ver o processo da reenquadramento do mundo" e, portanto, propícia à análise e à interpretação. Na mesma direção, também concordamos que a fotografia atua, concomitantemente, na semelhança que guarda com o mundo, como "autentificadora" da realidade que representa, e na dessemelhança percebida pelo sujeito "olhante", justamente por causa da consciência que ele tem de ver apenas parte da realidade, aquela enquadrada na fotografia. Aliás, o enquadramento é, para Charaudeau, um recurso discursivo bastante produtivo, sendo responsável por determinar o que estará visível (enquadrado), passível de um efeito de focalização e de dramatização, e o que estará não visível (fora do quadro). Mostrar, portanto, uma parcela da realidade e deixar seu entorno, por exemplo, de fora, é um recurso discursivo relevante, com potencial para a manipulação do "leitor", que pode subentender - ou não, por causa da ausência no enquadramento - sentidos e associações.

Por exemplo, no caso de uma das imagens que são objeto da análise aqui proposta, o rosto de uma mulher jovem, completamente machucado, marcado por linhas vermelhas que indicam a utilização de EPIs (indício reforçado pelo jaleco azul como aqueles que se usam nos hospitais, elemento imagético guardado em nossas memórias), Band-aid no nariz, olheiras, rabo-de-cavalo desmanchado, olhar fixo na câmera que a fotografou, é prova de uma realidade que se enquadra ${ }^{3}$. Imaginamos, ao redor, o não visível, provavelmente o ambiente em que, no hospital, os profissionais de saúde retiram o equipamento e roupas contaminados, como faz crer a reportagem em um jornal de referência como $O$ Globo. Já em outra situação, o entorno de um estúdio de gravação de uma série televisiva que tivesse essa mulher apenas como personagem ficcional poderia estar fora desse enquadramento, embora o visível estivesse preparado para impor, em função dos índices que aqui descrevemos, a associação do visível com um não visível relativo a frames cognitivos. No segundo caso, a não visibilidade de um hipotético estúdio corresponderia a um tipo de trucagem - que seria desmascarada se fosse possível ver o prolongamento da imagem, deixando visível por completo o ambiente com luzes, câmeras em tripés, fotógrafos, maquiadores.

Charaudeau (2013) também distingue que, na comunicação imagética, como na verbal, alguns efeitos são programados, visados, na textualização, de acordo com a intencionalidade do produtor - embora nem sempre sejam atingidos, isto é, efetivamente produzidos. No uso da

3 Infelizmente, precisamos optar pela descrição das imagens, em virtude da dificuldade para obter autorização para seu uso. Entretanto, os links em que as imagens podem ser recuperadas estão indicados em nota de rodapé na introdução deste artigo, para aqueles que desejarem maior compreensão das reflexões aqui propostas.

\section{LINHA D'́GUA}


imagem da profissional de saúde machucada pelos EPIs, é possível interpretar uma visada bastante dramatizante (como será analisado mais detalhadamente nas seções subsequentes), que se relaciona à realidade dos hospitais em tempos de covid-19 e, sobretudo, à atuação dos profissionais de saúde, muito sacrificados no combate à doença.

À esquerda da foto e no alto, aparece o título da reportagem, que é "Medo e exaustão: a jornada sem fim dos médicos de CTIs", especificando o sentido que o leitor deve dar à pessoa ali retratada na fotografia, já interpretando aquilo que pode ser inteligível na imagem. Essa parcela verbal tem seu sentido sensivel altamente ampliado em função da imagem, que conduz à intensidade daquilo que, dito, parece não mostrar a gravidade da situação. Nesse ponto, quase sempre anteriormente ao próprio reconhecimento (racional, inteligível) do conteúdo da imagem, ainda preso ao impacto do visto, ocorre (ou tem potencial para que ocorra) o efeito de sideração, ou seja, "uma impressão inexplicável, um sentimento insondável diante de outra coisa (representada) que acaba de nos tocar imediatamente pela potência de sua significância sem fala, sem decifração" (CHARAUDEAU, 2013, p. 391). Em outras palavras, somos levados ao irrepresentável, ao invisível. Essa reação emocional se soma à inferência sobre a gravidade à qual todos nós, médicos e pacientes, estamos expostos durante a pandemia. Somos levados pela emoção e pela interpretação a reter na memória essa imagem, tão difundida, como outras que simbolizam a atuação dos profissionais da saúde. Agora ela faz parte de nosso repertório mnemônico, marcada pelo afeto e pela empatia, e vai servir, futuramente, para novas interpretações, como uma imagem-sintoma já vista, "que remete a outras imagens por uma analogia" (CHARAUDEAU, 2013, p. 399).

Ainda em relação à pandemia, pode-se dizer que a máscara de proteção, tão insistentemente propalada como meio para evitar a covid-19, já se tornou símbolo dessa realidade, principalmente depois de ter sido colocada até em estátuas em vários locais do mundo, em um esforço de ampliação da campanha para seu uso. Na mesma revista $V e j a^{4}$ em que se encontra a publicidade, a capa apresenta, no centro, uma máscara amarela, com um sorriso desenhado, à guisa de um Smile, um emoticon bastante conhecido, que representa alegria relacionada à queda no número de internações e mortes pela covid. Também personagens de quadrinhos, artistas famosos em memes e posts, letreiros e lojas, marcas, nomes de jornais ganharam um máscara de proteção com o mesmo intuito, tornando-a não só difundida, mas também marcada como representante dessa experiência coletiva. A máscara, desde então, está presente no nosso dia a dia, não mais somente relacionada aos profissionais de saúde, mas a todo cidadão que se compromete a combater a disseminação da doença. A imagem da máscara, portanto, já pode ser tomada com um ícone repetido e carimbado, que provoca automaticamente inferências interdiscursivas.

Assim, a foto em close de Constanza Pascolato na publicidade da joalheria HStern, elegantemente penteada e maquiada, deixando à mostra as mãos com os anéis que pretende

4 Disponível em https://veja.abril.com.br/acervo/\#/edition/186185?page=1\&section=1. Acesso em 30 out 2020.

\section{LINHA D'́GUA}


anunciar, ao cobrir a boca e o nariz com parte da roupa em tom de prata, permite ao leitor não só uma reação emocional diante do gesto, como também uma interpretação que vincula essa imagem ao momento pandêmico, justamente por causa da sugestiva referência à máscara, ainda que de forma aparentemente improvisada, ou disfarçada. A foto ocupa quase a totalidade da página, tendo como âncoras apenas, em forma de legenda, a logo da joalheria, em letras maiores, e seu nome, em letras menores, na parte inferior da página (que, por causa dessa diagramação, serão percebidos e lidos após a apreensão da imagem). Apesar de não ser possível afirmar que esse sentido relacionado ao uso da máscara tenha sido visado, programado pelo enunciador (pela agência de publicidade, ou pelo fotógrafo, ou pela própria Constanza), em função da intericonicidade (COURTINE, 2013; CHARAUDEAU, 2013) que nos leva às máscaras da pandemia, é esse o sentido produzido.

Quando Courtine (2013) analisa fotografias impactantes tiradas por militares (incluindo mulheres) de torturados na prisão de Abou Ghraib após o fatídico 11 de setembro - fotos que se assemelham a souvenires de viagem -, a relação que estabelecemos entre a imagem que vemos e outras, armazenadas na memória, se iguala ao interdiscurso implícito na linguagem verbal. Diz ele:

Porque existem imagens debaixo destas imagens: na escolha de seus temas, na apresentação destes em quadros, na construção de um olhar pelos enquadramentos e pelas montagens que elas operam, na lógica do discurso que as ordena implicitamente em sequências, elas repetem o mais frequentemente, sem sabê-lo, outras imagens. Da mesma forma que existe o "sempre já" do discurso, existe $o$ sempre já da imagem. (p. 156. Grifos do autor)

Assim, justifica-se a leitura do rosto coberto de Constanza Pascolato como uma sugestão de referência ao momento que vivemos justamente por causa de nossa lembrança de tantas imagens com máscara, que povoam nossa visão e nosso imaginário. $\mathrm{O}$ impacto dessa imagem no leitor pode ocorrer por várias vias: pelo reconhecimento de uma mulher proeminente na elite do país que participa, em função de sua identidade social, em uma campanha publicitária; pela singularidade de figurar, em uma campanha como essa, comumente ocupada por mulheres fiéis a um padrão de beleza, sempre jovens, uma senhora de cabelos brancos; ou, sobretudo, por essa pessoa que, surpreendentemente, participa da campanha, fazer um gesto que torna sua imagem semelhante a outras na pandemia.

A imagem fotográfica, então, além de ter um alto poder referencial para indicar, recoberta de fidedignidade, recortes da realidade em um enquadramento dado, alcança, também, tanto pelos recursos discursivos próprios desse tipo de semiose quanto pelos conteúdos que comunica, sempre imersos em História, em cultura e em experiência individual, a memória dos "leitores", além de fisgar-lhes a atenção e a emoção em textos da mídia, muito compactos e impactantes, como dissemos anteriormente. Sua leitura, portanto, precisa começar na observação dos suportes, dos gêneros discursivos nos quais aparecem dispostas, na possível relação com a palavra, para, então, ser possível realizar inferências sobre a intencionalidade que subjaz o enunciado.

\section{LINHA D'ÁGUA}


Segundo a Teoria Semiolinguística de Análise do Discurso, a intencionalidade atravessa todo ato de linguagem, construindo pontes entre os interlocutores em uma encenação em que papéis linguageiros são postos em prática como um jogo de máscaras na interpretação teatral, de acordo com um determinado contrato de comunicação. Assim, o sujeito se apresenta ao outro construindo sua imagem discursiva, seu ethos.

\section{0 ethos como estratégia de captação}

Todo ato de enunciação implica, para o locutor, a construção de uma imagem de si próprio. Os episódios da história que cada um conta têm sua unidade a partir do pressuposto de que cada indivíduo desenvolve certo conceito de si, ou seja, "a imagem de si não é senão uma convenção narrativa para unificar uma história"” (HARRÉ, 1999, p. 155, tradução nossa).

Essa imagem de si, projetada pelo locutor por meio de seu discurso, é designada, na Retórica tradicional, como ethos. Está mais em jogo a capacidade de transmitir credibilidade, de persuadir o alocutário, do que o caráter propriamente dito do locutor. Um dos segredos da persuasão tal como é analisada a partir de Aristóteles é, para o orador, dar de si mesmo uma imagem favorável, imagem que seduzirá o ouvinte e captará a sua benevolência.

Na Retórica, Aristóteles propõe dividir os meios discursivos que influenciam o auditório em três categorias: de um lado, o logos, que pertence ao domínio da razão e que concerne à argumentação ou ao conteúdo em si dos argumentos, o que torna possível convencer; de outro, o ethos e o pathos, que pertencem ao domínio da emoção e tornam possível emocionar. $\mathrm{O}$ pathos é voltado para o auditório, quando a persuasão ocorre a partir da disposição dos ouvintes e concerne ao afeto e à paixão, já o ethos é voltado para o orador, relacionando-se à virtude e ao caráter, aos atributos deste, isto é, aos traços de caráter que o orador mostra ao público.

Vale observar, no entanto, seguindo Auchlin (2001, p. 204), que "o pathos designa as emoções vividas pelo auditório, mas o ethos também mobiliza as disposições afetivas do auditório". O ethos não se constrói naquilo que se diz, mas na maneira de dizer, no que o orador transmite, ou seja, trata-se do que ele apresenta, e não do que representa, já que se firma nas marcas da enunciação.

O homem, segundo Aristóteles, é um animal (pathos) político (ethos) capaz de falar e pensar (logos). Sua maneira de atuar, apoiando-se nessas três dimensões de seu ser, constitui, de acordo com Eggs (2005, p. 42), seu ethos. Assim, "todo ethos constitui uma condensação específica dessas três dimensões".

Essas categorias da Retórica foram deixadas de lado por um tempo, sendo exploradas, a partir do século XVIII, pela Estilística. Reapareceram recentemente, sobretudo, com o desenvolvimento dos estudos relativos à argumentação. A ideia de ethos foi, então, retomada e

5 “le soit n'est q'une convention narrative pour unifier une histoire.” (HARRÉ, 1999, p. 155)

\section{LINHA DÁGUA}


redefinida por alguns pesquisadores da Análise do Discurso, principalmente, por Dominique Maingueneau, a partir da década de 1980.

Assim, a noção de ethos passa a ser trabalhada em direções que ultrapassam o quadro da argumentação na tradição retórica, permitindo refletir sobre o processo mais geral da adesão de sujeitos a certa posição discursiva.

Maingueneau assim caracteriza o ethos:

o ethos é uma noção discursiva, ele se constrói através do discurso, não é uma "imagem" do locutor exterior à sua fala; o ethos é fundamentalmente um processo interativo de influência sobre o outro; é uma noção fundamentalmente híbrida (sócio-discursiva), um comportamento socialmente avaliado, que não pode ser apreendido fora de uma situação de comunicação precisa, integrada ela mesma numa determinada conjuntura sócio-histórica. (MAINGUENEAU, 2008, p. 17).

No caso das duas imagens em análise, fica clara a conjuntura socio-histórica e a situação comunicativa em que se inscrevem, no ano em que o mundo foi assolado pela pandemia do coronavírus, tornando-se evidente a intencionalidade dos enunciadores, no processo interativo de influência sobre o público receptor, ao mobilizarem as marcas evidenciadas nas imagens como estratégia de captação desse público.

A esse respeito, é importante salientar quem são esses sujeitos enunciadores que idealizam e constroem essas imagens discursivas como ethos mostrado por essas mulheres, ou seja, um ethos pré-construído por esses sujeitos enunciadores para instanciar a participação dessas mulheres na cena enunciativa. Na verdade, trata-se de um sujeito enunciador compósito,

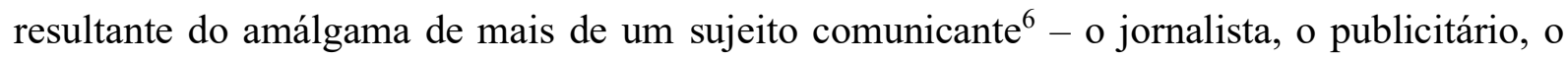
fotógrafo - que se mostra pelas mulheres fotografadas. Por outro lado, pode-se pensar que as instâncias compósitas abrem espaço para que as personagens femininas projetem suas imagens. No caso de $O$ Globo, podemos flagrar a construção do ethos da mulher pelo dito em discurso direto: trata-se uma imagem de si construída pelo que ela diz - "A máscara machuca o rosto; são muitas horas". E a fotografia aponta exatamente para esse ethos projetado por ela em dimensão verbal. Ao escolher projetar essa fala e essa imagem, a instância midiática revela a pertinência de tratar desse ethos feminino.

Já em relação à publicidade, parece-nos que a empresa (HStern) pretende assumir a face de Constanza, elegante, com muito bom gosto e consciente, pois, pela projeção do ethos mostrado da estilista, a HStern projeta uma imagem de si.

Vale destacar que o status social do locutor e a legitimidade que detém permitem ao auditório construir uma imagem antes mesmo que se inicie o texto - seria o ethos prévio (ou pré-discursivo). Por outro lado, as reconfigurações estabelecidas pelo locutor, a partir do momento da interação, podem transformar essa imagem, já que é uma estratégia confirmar esse ethos pré-discursivo ou modificá-lo, segundo as intenções do próprio orador - esse seria o ethos discursivo.

6 Para aprofundamento das noções de sujeito comunicante e sujeito enunciador, ver CHARAUDEAU, P. Linguagem e discurso: modos de organização. São Paulo: Contexto, 2008.

\section{LINHA D'́GUA}


Nesse sentido, a noção de ethos se aproxima da noção de "representação de si mesmo", postulada por Goffman (1999), segundo a qual em cada circunstância da vida cotidiana, o indivíduo apresenta uma imagem de si (voluntária ou involuntariamente) em função do objetivo da interação. Utiliza-se o autor de uma metáfora, tomando, do teatro, o termo representação. A representação seria, então, a totalidade da atividade desempenhada por um sujeito, em uma dada ocasião, para influenciar o outro, o que implicaria a definição de uma posição social a ser ocupada por esse sujeito. A isso, Goffman denomina "fachada". A caracterização da "fachada" pode ser visualizada tanto do ponto de vista do que se considera como "fachada social" - para especificar o que é comum aos sujeitos pertencentes a um mesmo grupo específico, representando o que é permitido e o que é obrigado a todos ("representação coletiva") - quanto do ponto de vista do que é considerado como "fachada pessoal" - para referir-se a tudo o que, de maneira mais íntima, identifica o próprio sujeito, ou seja, as formas egocêntricas da territorialidade.

Dessa forma, nesse modelo, considera-se que todo indivíduo possui duas faces: uma face positiva, que corresponde à "fachada" social, à nossa própria imagem valorizada, que pretendemos apresentar aos outros e uma face negativa, que corresponde ao "território" de cada um - seu corpo, sua intimidade (GOFFMAN, 1980).

Em uma acepção goffmaniana, portanto, todo ser humano, apreendido como sujeito, vive em um mundo social, no qual se encontra em contato com outros sujeitos. Por meio desses contatos, é levado a exteriorizar, por representações, uma imagem de si.

Seria interessante destacar que tanto na imagem da profissional de saúde, quanto na de Constanza Pascolato, essas duas "fachadas", ou "ethos mostrado", no dizer de Maingueneau (2008), parecem se mesclar, sobrepondo-se o social ao individual, frente à situação extrema por que o mundo passa neste momento.

O ethos de um discurso resulta, portanto, de uma interação entre diversos fatores: ethos pré-discursivo, ethos discursivo (ethos mostrado) e ainda de fragmentos de texto em que o enunciador evoca sua própria enunciação (ethos dito) direta ou indiretamente, e, nesse último caso, por meio de metáforas, alusões a outras cenas.

Percebe-se, dessa forma, que as imagens projetadas pelo ethos são governadas, no contexto extralinguístico, pelos imaginários sociodiscursivos, ou, na interpretação de Moscovici (2013) na Psicologia Social, pelas representações sociais de uma dada coletividade. Assim, o real não é apresentado a partir de uma descrição objetiva, mas por meio de representações veiculadas pelo enunciador a fim de induzir seu interlocutor a construir, a partir dos fragmentos apresentados, um mosaico que ele tomará como verdade, sendo todo esse processo intermediado pela linguagem, seja verbal, seja não verbal.

A esse respeito vale destacar a importância da relação locutor/alocutário na construção do ethos. Charaudeau (2006, p. 115) assinala que o ethos é resultante do cruzamento de olhares - "olhar do outro sobre aquele que fala, olhar daquele que fala sobre o modo como ele pensa

\section{LINHA D'́GUA}


que o outro o vê". O sujeito aparece ao olhar do outro com uma identidade psicológica e social que lhe é atribuída e se mostra conforme a identidade discursiva que ele mesmo constrói para si e, assim, as identidades discursiva e social se fundem no ethos.

Por outro lado, não se pode perder de vista que o sujeito enunciador pode jogar com máscaras, escondendo o que realmente é por trás das palavras que diz, ao mesmo tempo em que seu interlocutor o interpreta pelo que ele diz e não pelo que efetivamente é.

Nesse sentido, Charaudeau comenta que:

Várias máscaras são possíveis, e, portanto, várias identidades são possíveis: mudamos a situação de troca, e o outro, que também o sabe, sabendo-o pode-se jogar com as máscaras, e o outro, que também o sabe, entrará no jogo. Tiramos a máscara e o que encontramos sobre ela? Outra máscara, depois outra e depois mais outra. A máscara é o que constitui a nossa identidade em relação ao outro. (CHARAUDEAU, 2006, p. 8)

Como já observado, Constanza Pascolato cobre o rosto com a roupa que veste e simula o uso de uma máscara, o que é bastante sintomático na conjuntura atual. A profissional de saúde, ao contrário, tem o rosto livre da máscara (ou do shield que deve ter tirado), mas pleno de marcas, que constroem a sua identidade, forjando seu ethos mostrado.

Que nos dizem essas imagens? Como nos afetam? Tiramos as máscaras e o que encontramos? Muitas outras máscaras que se vão sobrepondo em uma (re)construção sem fim constitutiva de nossa marca identitária.

\section{0 pathos como efeito visado}

Nas diversas situações-contratuais, a sobreposição de máscaras é sempre possível e, portanto, as diferentes identidades assumidas a cada troca também o são. Isso porque, modificando-se a situação comunicativa, substituem-se as máscaras. Uma vez que o sentido, oriundo de todo ato de linguagem, resulta do encontro entre quem enuncia e quem interpreta em função do que um imagina do outro, salienta-se que as identidades/máscaras projetadas são verdadeiras co-construções resultantes desse encontro. Dessa forma, nas diversas relações contratuais intersubjetivas, cada sujeito é para o outro tão somente uma imagem.

Não se trata, contudo, da projeção de uma aparência falsa, não sendo a máscara tomada aqui como um artificio dissimulador, tão caro, por vezes, à ficção, no mundo ocidental, como ilustram as pessoas mascaradas de Zorro ou de Batman ${ }^{7}$. Faz-se referência aqui à máscara/imagem constitutiva do próprio sujeito em sua verdade de troca, a designar, portanto, um ser presente, apartado de dissimulações, na relação sempre atualizada diante do outro.

\footnotetext{
7 Zorro e Batman são dois personagens de ficção, tendo sido criados em 1919 e 1939, respectivamente. Os dois têm em comum o fato de terem uma identidade secreta (Don Diego de La Veja e Bruce Wayne), usarem roupas escuras e projetaram suas assinaturas ao final de cada ação heroica.
}

\section{LINHA DÁGUA}


E, se as trocas sociais estão sempre mesmo em atualização, os sujeitos atualizam, inevitavelmente, também, suas identidades. Assim, podem assumir variadas máscaras: “mudamos a situação de troca, substituímos as máscaras" (CHARAUDEAU, 2006, p. 8).

Caso emblemático dessa sobreposição de máscaras está no que se apresenta em decorrência da fotografia publicada na capa de $O$ Globo de 14 de maio de 2020, já mencionada neste artigo. Se a troca contratual típica da relação médico-paciente, em um hospital de combate à covid-19, impõe o uso da máscara (shield), segundo as restrições situacionais da troca, constituindo a identidade da pessoa que a utiliza como um/uma profissional de saúde responsável e atuante na linha de frente no combate à doença, sua retirada nos dá a ver uma outra máscara. Sob a primeira máscara, está uma outra identidade, desvelada agora pela instância midiática diante de seu público-alvo. A nova máscara fotografada por $O$ Globo corresponde à imagem de uma profissional que está para além da atuação médica responsável; por detrás do equipamento facial de proteção individual, emerge uma identidade feminina (trata-se de fotografia de uma mulher) que atua no limite de suas forças (as marcas/feridas deixadas pelo EPI sobre a face da mulher traduzem o longo, árduo e doloroso tempo de trabalho da profissional, como comprova, inclusive, a fala reportada por $O$ Globo: "A máscara machuca o rosto, são muitas horas”) em pleno contexto de uma epidemia planetária.

Das duas situações-contratuais descritas - do domínio médico-hospitalar e do domínio jornalístico -, constata-se o fato de que, a cada máscara utilizada, estabelece-se um novo jogo comunicativo entre os parceiros da troca. Em cada um dos domínios citados, atribui-se, notadamente, ao leitor uma grade de leitura do signo imagético "máscara". Frente a essa imposição, delineia-se uma posição particular do leitor diante da ação de consumi-lo (o signo). Particularmente, diante do jornal $O$ Globo de 14 de maio de 2020, o receptor é instado a identificar-se a um leitor afetado plenamente pelas ações sacrificantes dos médicos no combate à covid-19.

Em outra direção, retomando a imagem já aqui referenciada de Constanza Pascolato, exibindo, elegantemente, sua "máscara prateada" enquanto apresenta as joias que porta, o signo "máscara" atribui ao leitor de antemão um outro lugar. Tratando-se de uma imagem que figura na propaganda da HStern, veiculada em revistas diversas, como Veja, o leitor é solicitado, agora, a consumir o signo "máscara" sob as exigências do contrato publicitário.

Assim, pode-se afirmar que os diferentes contratos, seja o jornalístico - correspondente ao que se estabelece frente à capa de $O$ Globo -, seja o publicitário - relativo à publicidade da HStern, publicada em Veja -, sobredeterminarão os sentidos construídos pelo leitor. E esses sentidos devem ser considerados, sobretudo, em relação aos visados ou supostos "efeitos patêmicos do discurso", assim denominados, por Charaudeau (2010, p. 26), no quadro de uma problemática discursiva das emoções.

No âmbito da Teoria Semiolinguística de Análise do Discurso, a categoria retórica do pathos é retomada, de fato, como uma importante estratégia dos discursos sociais a suscitar

\section{LINHA DÁGUA}


emoções sobre os sujeitos. Sob esse enquadramento teórico, há que se ressalvar que as emoções são evocadas na perspectiva de um efeito e não como realidade manifesta, vivenciada efetivamente por um sujeito. Daí, Charaudeau (2010, p. 35) preferir os termos "patêmico" e "patemização" ao vocábulo "emoção" e salientar que, na análise do discurso, a emoção deve ser considerada "fora do vivenciado, e apenas como um possível surgimento de seu 'sentido' em um sujeito específico, em situação particular” (2010, p. 34). Esse é um esclarecimento importante para justificar que, na análise aqui proposta, a emoção - como efeito - será, justamente, examinada de acordo com aquilo que a desencadeia, sempre na dependência da situação contratual e sociocultural em que a troca comunicativa se inscreve.

Em seu estudo da patemização das mídias, Patrick Charaudeau (2010) propõe uma estruturação do universo patêmico em torno de quatro grandes imaginários sociodiscursivos, ou tópicas, em relação aos quais se entrevê uma afetação polarizada em dimensão positiva e negativa, conforme o que se descreve a seguir: 'a tópica da 'dor' e seu oposto, a 'alegria'; a tópica da 'angústia' e seu oposto, a 'esperança'; a tópica da 'antipatia' e o seu oposto, a 'simpatia'; a tópica da 'repulsa' e seu oposto, a 'atração"” (CHARAUDEAU, 2010, p. 48). Toda essa organização das categorias patêmicas ecoa da aplicação de três parâmetros bem delimitados, a saber: o que o sujeito percebe de um actante-objeto (pessoa ou situação) rumo à projeção de certo afeto; o que sente (em termos de estado mental) o sujeito na relação que estabelece com o actante-objeto; e que comportamento enunciativo o sujeito assume frente à percepção de dado actante-objeto e da sensação diante da relação estabelecida entre ambos.

Em outras palavras, se estamos diante de um universo discursivo patemizante, é porque a certa pessoa ou situação (actante-objeto), sobre a qual se centra a troca comunicativa, é atribuído um estatuto, no quadro de uma rede de crenças, instaurador de um afeto determinado. Esse afeto, considerado na encenação discursiva da emoção, acaba por desencadear determinado estado (de satisfação ou de insatisfação, em termos gerais) a ser expresso por um sujeito, dotado de intencionalidade, sob determinado comportamento enunciativo prevalente: seja de maneira elocutiva (pela revelação do ponto de vista do locutor); seja de modo alocutivo (para estabelecimento da posição do sujeito falante na relação com o outro); seja de forma delocutiva (pela remissão à fala de um terceiro).

Para exemplificar, retomemos a matéria de capa de $O$ Globo de 14 de maio de 2020, intitulada: "Medo e exaustão: a jornada sem fim de médicos de CTI", destacando-se, respectivamente, o texto verbal (i), que figura ao lado da imagem fotográfica da médica Roberta de Lima, em cuja face se identificam feridas pelo uso prolongado do equipamento de proteção hospitalar, e a legenda (ii) da foto:

(i) "Imagens de aglomerações na cidade assustam os médicos intensivistas que atuam no Rio. Eles sabem que a baixa adesão ao isolamento levará ainda mais doentes aos hospitais já saturados, onde disputarão leitos em CTIs. E temem que o pico de casos já alcançado se torne o padrão;

(ii) Sem descanso. Roberta Lima: 'A máscara machuca o rosto; são muitas horas””.

\section{LINHA D'́GUA}


Do que se lê, depreende-se que a encenação discursiva ali proposta pauta-se, principalmente, sobre os imaginários sociodiscursivos da "angústia/medo" e da "dor".

Relativamente à primeira tópica, da "angústia/medo", há que se considerar que ela:

a) em nome de uma rede de crenças que associa representações negativas a epidemias e à desobediência sanitária, é desencadeada pela situação de trabalho de médicos atuantes em CTIs cariocas durante a pandemia da covid-19, frente às insistentes aglomerações na cidade do Rio.

b) traduz-se por um estado de espera por algo ainda mais negativo (aumento do número de casos de pacientes infectados), a representar um perigo para o sujeito, no caso, os médicos intensivistas que trabalham nos hospitais cariocas.

c) enuncia-se de maneira delocutiva, conforme o que se pode depreender, por exemplo, dos trechos que se seguem a pontuar a angústia daqueles que assumem a posição de quem se sente sob ameaça: "Imagens de aglomerações na cidade assustam os médicos intensivistas que atuam no Rio" e "E temem que o pico de casos já alcançado se torne padrão”.

A respeito da segunda tópica, da "dor", é válido ressaltar que ela:

a) em relação a uma rede de crenças que coloca os médicos em posição de vítimas colaterais da epidemia, é desencadeada pela situação adversa vivida pelos médicos intensivistas em contexto pandêmico;

b) traduz-se por um estado de insatisfação do desejo do sujeito (de mal-estar e abatimento), o que se entrevê, sobretudo, pela imagem abatida da médica Roberta de Lima publicada pelo jornal;

c) enuncia-se de maneira tanto delocutiva, quanto elocutiva, em conformidade com o que se pode comprovar pelos trechos a seguir transcritos, respectivamente: "A jornada sem fim dos médicos de CTI" e "Roberta Lima: "A máscara machuca o rosto, são muitas horas'."

Corrobora a análise proposta a explicitação, no texto verbal de $O$ Globo, de uma abundância de palavras e expressões pertencentes, claramente, ao universo emocional da 'angústia', como: "Medo"; "assustam"; "temem". Por seu turno, os termos "exaustão"; "sem fim"; "sem descanso" produzem também um efeito patêmico, agora relacionado à tópica da 'dor'.

Diante dos exemplos aqui apresentados, relativos ao funcionamento da materialidade verbal das emoções, há que se ponderar que os signos assumem tão somente o papel de produzir efeito patêmico na convergência com as determinações socioculturais e os raciocínios inferenciais mobilizados pelos interagentes. Nesse sentido, o efeito patêmico suposto depende não apenas dos signos empregados na troca, mas também das inferências produzidas pelos parceiros do ato comunicativo, dependentes do conhecimento que eles podem ter da situação enunciativa (CHARAUDEAU, 2010, p. 38).

\section{LINHA DÁGUA}


Particularmente, diante do caso em tela, verifica-se que a exposição do fato é feita sob a situação enunciativa midiática. Sob o polarizado contrato da comunicação jornalística, a instância midiática de produção (informador profissional) se coloca, idealmente, no papel de encenar o fato com vistas a "fazer o outro saber" (informar) sobre o espetáculo do mundo na sua atualidade, em vista de seu compromisso com a credibilidade. Quando esse espetáculo da informação é encenado também sob uma visada (finalidade) dramatizante, em razão de seu compromisso com a captação, o discurso da informação passa a ser ainda portador de patemias, como, por exemplo, a "angústia" e a "dor". Isso fica bem evidente, no corpus sob análise, pela exposição do espetáculo do "sofrimento" vivenciado por médicos intensivistas (vítimas colaterais) em CTIs e, em particular, pela médica Roberta de Lima.

A menção jornalística à médica, em sua singularidade verbo-visual, evita que o jornal encene o acontecimento pela amostragem de uma "máscara neutra", com a qual o leitor não pode se identificar. $\mathrm{O}$ apontamento do privado (no jogo de relação com o espaço público) pelo discurso midiático potencializa a emersão de efeitos patêmicos sobre o leitor na direção de uma humanização da cena (pela menção ao caso singular da médica Roberta de Lima) e de uma identificação catártica (pelo ingresso na intimidade dolorosa da médica citada) ou mesmo de uma espetacularização do ato heroico de salvamento do outro (pela citação ao fato de que, diante da saturação, os médicos intensivistas cumprem sua “jornada sem fim”) (CHARAUDEAU, 2010, p. 47).

A respeito da humanização da cena construída discursivamente, parece válido destacar uma ideia de Ellsworth (2001) para quem, a fim de que um filme dê certo frente a um determinado auditório, o espectador deve tecer uma relação particular com a história. Acerca disso, Gomes destaca que, entre as estratégias possíveis de criação desse efeito, está a da humanização do relato, calcada, com certa predominância, em "enquadramentos em close e planos fechados que evidenciam os 'rostos' muitas vezes anônimos” (2005, p. 14, grifos nossos).

Vale complementar essa ideia mencionando ainda, junto com Charaudeau (2010, p. 47), que "o surgimento do privado tem uma função de compaixão-ação" diante do acontecimento encenado. No exemplo extraído de $O$ Globo e aqui examinado, é possível salientar que o acontecimento encenado pelo discurso é projetado tanto como uma verdadeira "desordem social”, com suas vítimas colaterais - os médicos intensivistas e suas angústias/medos - quanto como uma espécie de "reparação", com seus heróis - os médicos intensivistas, com suas dores físicas e morais.

Para arrematar esta seção, há que se ressaltar que, na utilização bastante referencial da face fotografada da profissional de saúde ferida pelo EPI, em diálogo com o texto verbal que a acompanha, vislumbra-se a intencionalidade de se colocar o leitor em uma dupla posição. Ao mesmo tempo em que é instado a compartilhar do "medo" sentido pelos médicos, é também posto no papel de testemunha impotente frente à atuação sacrificante (de "dor") dos profissionais da saúde que estão na linha de frente do combate à doença. Assumindo essa dupla 
posição, atesta-se que o sujeito é passível de ser afetado patemicamente em razão do potencial de referencialidade do contrato midiático. Segundo Charaudeau, esse contrato "se justifica pela sua referencialidade e é esta referencialidade que é garantia do efeito de patemização: preciso saber que o sofrimento é realmente vivido por meu outro-eu-mesmo para que eu possa me sentir emocionalmente concernido" (CHARAUDEAU, 2010, p. 45).

Aliás, residiria justamente nisso a diferença entre o contrato publicitário e o contrato midiático. Conforme pontua o professor Charaudeau (2010, p. 45), a narrativa publicitária, sendo pura invenção, não necessitaria do apoio de uma realidade. Disso decorre que o interlocutor acaba por não se projetar gratuitamente nos personagens desse tipo de narrativa. No caso particular da publicidade da HStern, parece ter havido, contudo, uma brecha para a colocação da referencialidade em cena, relacionada à realidade pandêmica. Como já examinado nas seções precedentes, a imagem fotográfica de Constanza Pascolato mostra que, além de ela exibir as joias que traz nos dedos, simula também o uso de uma máscara, signo de uma realidade realmente vivida pela audiência. Isso acaba por deixar em evidência um efeito patêmico, programado pela instância publicitária, correspondente à sensibilização do consumidor para o uso do equipamento, e não somente das joias, na proposição de um espelhamento da modelo reconhecida por sua elegância e bom-gosto - nos atos do(a) consumidor(a). Em suma, da análise dessa publicidade, depreende-se a inegável ideia de que se fala de um acontecimento "real" (a pandemia da covid-19 e suas restrições) com a intencionalidade de exaltação de um produto comercial (as joias da HStern).

\section{Escrever com mão alheia, de mãos dadas com o mediador}

Affonso Romano de Sant'Anna (2011), em uma de suas notáveis crônicas, afirma que "ler é uma forma de escrever com mão alheia". Nesse texto, ele discorre sobre o fato de que lemos tudo ao nosso redor: lemos o corpo dos outros (assim como leem o nosso); as paisagens; os desfiles das escolas de samba; uma partida de futebol; a história antiga em ruínas; a natureza; as cartas... E completa: "Tudo é leitura. Tudo é decifração. Ou não. Ou não, porque nem sempre deciframos os sinais à nossa frente" (SANT'ANNA, 2011, p.10). Essa leitura-decifração pode estar, muitas vezes, contida na leitura (em sentido estrito) de outros textos, aqueles que efetivamente estão em jornais, livros, revistas, ou nas fotografias que vemos, sempre acompanhando o ponto de vista de quem os produziu. Lemos, vemos, compreendemos aquilo que nos é mostrado por alguém de acordo com sua perspectiva.

No caso dos textos da "grande mídia", como os que são veiculados por jornais e revistas impressos e on-line, pode-se pensar em um "primeiro estágio" de leitura, feita pelo próprio produtor em relação à realidade que vê; ele recorta o mundo a partir de suas escolhas e o oferece, parcial e direcionadamente, ao outro, leitor "acostumado" com os veículos de massa com os quais se depara. O leitor dos jornais e revistas, então, em um "segundo estágio", interpreta essa realidade já recortada e significada, devendo considerar o recorte como estratégia de

\section{LINHA DÁGUA}


significação altamente potente. Essa habilidade para perceber a intermediação do produtor do texto, do dispositivo que permite sua veiculação, a situação comunicativa que envolve esses dados e os organiza, é desenvolvida ao longo das leituras cotidianas; é uma habilidade estreitamente ligada à crítica, que dota o leitor da capacidade para não considerar "natural" tudo o que lê e vê nas revistas, mas sim um constructo social, baseado nas interações e nas hierarquias estabelecidas na ação recíproca dos indivíduos em seus grupos.

Esse aspecto é suficiente para pensarmos na importância de uma "educação leitora", a partir de uma mediação, provavelmente do professor, que possa acompanhar o ato de ler do estudante, a fim de levá-lo a perceber as estratégias de implicitação de conteúdo e de valores utilizadas pelos produtores - sobretudo os da "grande mídia". O jornalismo e a publicidade, portanto, de fácil acesso por parte do público em geral, além das expectativas automaticamente criadas pela natureza mesma dos veículos de comunicação e dos gêneros discursivos em si, precisam ser "lidos" em sua inteireza, em sua intencionalidade própria. E esse refinamento na leitura pode e deve ser desenvolvido ao longo do processo de letramento, quase sempre de responsabilidade da escola. O professor-mediador, então, na consciência de seu papel como aquele que vai despertar o olhar crítico do estudante, precisa de embasamento para realizar atividades de capacitação leitora, nas quais pode "dar a mão" para o aluno e conduzi-lo pelas estratégias de leitura com as quais vai adquirir autonomia para leituras vindouras. A própria BNCC orienta os educadores em relação a isso, como vimos na introdução deste trabalho.

De acordo com os conceitos e com as análises aqui apresentados, podemos considerar viável, por exemplo, uma atividade de leitura no Ensino Básico que coloque um holofote sobre alguns aspectos, no intuito de despertar essa leitura crítica de que falamos. Em relação à análise das imagens em si, pode-se partir da simples identificação das personagens ali representadas, não simplesmente em sua singularidade, mas, sobretudo, naquilo que significam para a sociedade. Descreve-se, portanto, em um primeiro momento, a denotação das imagens, sua referencialidade, observando a superfície da parcela visual das fotografias em relação à verbalidade que as ancora. É a fase das inferências centrípetas de que trata Charaudeau (2018), como discorremos a respeito. Da apreensão dessa imagem material, parte-se para um segundo momento, no qual é possível fazer inferências centrífugas e observar a conotação das imagens, aquilo que se superpõe ao enquadramento propiciado pela fotografia, de natureza "realística" e menos ficcional, composta por "elementos do mundo" igualmente interpretáveis.

Um possível comando para uma atividade direcionada aos anos finais do Ensino Médio, com o objetivo de observar e interpretar as imagens que participam dos textos aqui analisados, poderia ser configurado da seguinte maneira: Descreva a fotografia que compõe a notícia/a publicidade em tela, associando-a às informações dadas pelo texto verbal que a cerca. A que parcela da realidade a fotografia faz referência? Conclua: de acordo com a intencionalidade do gênero discursivo ao qual pertence o texto, o que justifica a escolha da personagem ali figurada? O que ela representa em nossa sociedade para ter sido escolhida? Um comando nesses moldes pode conduzir o leitor da materialidade da imagem à interpretação de sua

\section{LINHA DÁGUA}


significação de acordo com o grupo social no qual circula o texto. A passagem da denotação à conotação se dá na observação de traços concretos presentes nas fotografias (rosto machucado, o Band-aid, o jaleco azul; o rosto maquiado, a elegância da senhora, a riqueza dos ornamentos) na direção daquilo que esse conjunto de índices pode deixar implícito (o sofrimento dos profissionais de saúde; a elegância e a credibilidade conquistada pela célebre estilista, além da referência à pandemia), que está a serviço dos objetivos daquele gênero discursivo. $\mathrm{O}$ comando, então, conduz o leitor à interpretação, passando por estratégias variadas até que se alcancem as inferências centrífugas que possibilitam finalizar a compreensão.

Em relação ao ethos como estratégia de captação, um comando plausível poderia ser constituído assim: Considerando o gênero discursivo a qual se filia a notícia/a publicidade, o fato de uma mulher figurar como representante da ideia que se veicula tem uma motivação. Qual? Como a escolha de uma mulher - e dessa mulher-pode influenciar a identificação do leitor com o texto? Dando continuidade ao processo de interpretação, esse tipo de comando focaliza especificamente o papel do ethos mostrado pelas personagens, criando uma identidade na qual o leitor pode se espelhar, seja na sugestão da máscara e dos EPIs utilizados pela médica na fotografia da reportagem (em função das marcas no rosto), seja na sugestão da máscara na fotografia da estilista famosa da publicidade (em função do gesto), ambas estreitamente ligadas ao momento histórico da pandemia que vivenciamos. A captação do leitor se funda no impacto da imagem, ocupando um espaço bastante relevante na página, atraindo o olhar para o sofrimento coletivo, no primeiro caso, e para a elegância, mas também para o vivido coletivo, no segundo caso.

Em paralelo, relativamente ao pathos como efeito visado, outra questão poderia ser assim comandada: Em vista de um dos gêneros discursivos em tela (a notícia), constata-se a presença de estratégias linguístico-discursivas que colocam em tensão a dupla finalidade do texto: a credibilidade e a captação do leitor. Que expedientes seriam esses? Como tais recursos afetam o leitor? Em comparação ao gênero publicitário, verifica-se também a dupla finalidade de credibilidade e de captação no texto em questão? As estratégias vinculadas a esse duplo compromisso afetam o leitor do mesmo modo que a notícia? No processo de interpretação, o comando sugerido solicita, primeiramente, uma tomada de consciência relativa ao compromisso que a instância jornalística tem com a credibilidade. Tal compromisso pode ser materializado pela exposição a fatos do mundo em sua atualidade, neste caso relacionados à pandemia da covid-19, à situação atinente à "baixa adesão ao isolamento" e à "jornada de médicos de CTI". Além disso, focalizando, especialmente, o pathos como um efeito visado, o comando proposto possibilita também que se entreveja que a mídia está comprometida com a captação do público-alvo. Esse compromisso ganha materialidade, por exemplo, pela exposição dos fatos do mundo sob signos da dramatização, flagrados pelo emprego do caso particular da médica "Roberta de Lima" e de sua explícita dor ("A máscara machuca") ou ainda pela temerosa ("Medo") e longa ("Exaustão") jornada enfrentada pelos heroicos médicos dos CTIs. Todos esses recursos, estrategicamente empregados, encenam uma realidade que produz a ideia de que o sofrimento é mesmo vivido. Nesse sentido, afetam em cheio o leitor que se sente

\section{LINHA D'́GUA}


emocionalmente capturado seja pelo medo ou pela impotência frente à dor sentida pelos profissionais da saúde. Por sua vez, diante do gênero publicitário também explorado no comando supracitado, a afetação do leitor parece estar a cargo do potencial de referencialidade (credibilidade) inesperadamente inscrito no texto. A referência à pandemia pelo filtro metonímico de uma "máscara prateada" - joia em tempos de doença epidêmica - é mecanismo explícito sedutor colocado a serviço da finalidade pragmática da publicidade, de fazer o outro comprar.

Entre rostos, afetos e intencionalidades, no que diz respeito à imagem como signo, ao ethos como estratégia de captação e ao pathos como efeito visado dos discursos sociais, as análises semiolinguísticas aqui propostas, concernentes aos contratos jornalístico e publicitário, dão margem ainda para uma última reflexão importante no contexto da educação linguística. A nosso ver, é ação necessária para a educação geral de um povo dar-lhe consciência de que há encenações discursivas que são mais dramatizantes do que outras. Nesse sentido, encorajá-lo a resistir aos afetos, cuja face apresenta-se, por vezes, excessiva e ardilosa - não na direção de apagá-los, mas de controlá-los - parece uma necessidade no quadro da formação de cidadãos mais críticos e atuantes.

\section{Referências}

AUCHLIN, A. Ethos e experiência do discurso: algumas observações. In: MARI, H.; MACHADO, I. L.; MELO, R. (Org.). Análise do discurso: fundamentos e práticas. Belo Horizonte: Núcleo de Análise do Discurso - FALE/UFMG, 2001.

BARTHES, R. O óbvio e o obtuso. Rio de Janeiro: Nova Fronteira, 1990.

BRASIL. Ministério de Educação. Base Nacional Comum Curricular. 2017

CHARAUDEAU, P. Compréhension et interpretation: interrogations autour de deux modes d'appréhension du sens dans les sciences du langage. In: ACHARD-BAYLE, G.; GUÉRIN, M.; KLEIBER, G.; KRYLYCHIN, M. (org.). Les sciences du langage et la question de l'interprétation (aujourd'hui). Limoges, Les Éditions Lambert-Lucas, 2018. p. 21-55. Disponível em português em: https://ciadrj.letras.ufrj.br/2019/11/21/novo-artigo-de-patrickcharaudeau-traduzido. Acesso em 16 jun. 2020.

CHARAUDEAU, P. Imagem, mídia, política: construção, efeitos de sentido, dramatização, ética. In: MENDES, E. (coord.); MACHADO, I. L.; LIMA, H.; LYSARDO-DIAS, D. (orgs.). Imagem e discurso. Belo Horizonte: FALE/UFMG, 2013. p. 383-405.

CHARAUDEAU, P. A patemização na televisão como estratégia de autenticidade. In: MENDES, E.; MACHADO, I. L. (orgs.) As emoções no discurso. v. II. Campinas: Mercado das Letras, 2010.

CHARAUDEAU, P. Discurso Político. São Paulo: Contexto, 2006.

CHARAUDEAU, P. Linguagem e discurso - modos de organização. São Paulo: Contexto, 2008.

COURTINE, Jean-Jacques. Decifrar o corpo: pensar com Foucault. Petrópolis: Vozes, 2013. 
EGGS, E. Ethos aristotélico, convicção e pragmática moderna. In: AMOSSY, R. (Org.). Imagens de si no discurso. A construção do ethos. São Paulo: Contexto, 2005.

ELLSWORTH, E. Modos de endereçamento: uma coisa de cinema; uma coisa de educação também. In: SILVA, T. T. (Org.). Nunca fomos humanos - nos rastros do sujeito. Belo Horizonte: Autêntica, 2001. p. 7-76.

GOFFMAN, E. A representação do Eu na vida cotidiana. 8. ed. Petrópolis: Vozes, 1999.

GOFFMAN, E. A elaboração da face. Tradução Jane Russo. In: FIGUEIRA, S. A. (Org.). Psicanálise e Ciências Sociais. Rio de Janeiro: Francisco Alves, 1980.

HARRÉ, R. Grammaire et lexiques, vecteurs des representations socials. In: JODELET, D. Les représentations sociales. Paris: PUF, 1999.

GOMES, I. M. M. et al. Modo de endereçamento no telejornalismo do horário nobre brasileiro: o Jornal Nacional, da Rede Globo de Televisão. In: CONGRESSO BRASILEIRO DE CIENNCIAS DA COMUNICAÇÃO - INTERCOM, 28, 2005, Rio de Janeiro. Congresso... Rio de Janeiro: [s.n.], 2005. Trabalho apresentado ao NP 07 - Comunicação Audiovisual.

GUIMARÃES, R. N. Estratégias de captação em capas-cartazes do Jornal Popular Meia Hora. 2020. Tese (Doutorado em Linguística) - Instituto de Letras, Universidade Federal Fluminense, Niterói, 2020. Disponível em: https://app.uff.br/riuff/handle/1/14565. Acesso em 09 nov 2020.

MAINGUENEAU, D. A propósito do ethos. In: MOTTA, A. R.; SALGADO, L. (Org.). Ethos discursivo. São Paulo: Contexto, 2008.

MOSCOVICI, S. Representações sociais: Investigações em psicologia social. Petrópolis: Vozes. 2013.

SANT'ANNA, A. R. Ler o mundo. Rio de Janeiro: Global Editora, 2011.

SANTAELLA, L.; NÖTH, W. Imagem: cognição, semiótica, mídia. 4.ed. São Paulo: Iluminuras, 2005.

SELLES, S. E. A BNCC e a Resolução CNE/CP n 2/2015 para a formação docente: a "carroça na frente dos bois". In: Caderno Brasileiro de Ensino de Física, v. 35, n. 2, p. 337-344, ago. 2018. Disponível em: https://periodicos.ufsc.br/index.php/fisica/article/view/21757941.2018v35n2p337. Acesso em 29 out 2020.

Recebido: 07/12/2020.

Aprovado: 05/03/2021. 